\author{
Olga Kraśniewska \\ University of Wroclaw \\ krasniewskao@gmail.com
}

\title{
A country held captive by its past: The case of Zimbabwe
}

Date of submission: $20^{\text {th }}$ of March 2018; date of acceptance: $15^{\text {th }}$ of May 2018

JEL Classification: A10, E31, F54, N37, O55

Keywords: Zimbabwe, colonialism, land reform, hyperinflation, Robert Mugabe, crisis

\begin{abstract}
A country held captive by its past: The case of Zimbabwe

The article provides an overview of the history of Zimbabwe in the context of economical, structural and social factors. It tries to answer a question, what were the main reasons that affected Zimbabwe's development after gaining independence in 1980. It describes pre-colonial and colonial times as well as president Mugabe's era, that ended with a military coup in November 2017. It portrays issues such as the after-effect of colonialism, land reform, political regime, internal struggles and conflicts between the ruling party ZANU-PF and opposition parties, hyperinflation crisis, as well as economic indicators like GDP, public and external debt, level of education and health care. In the context of upcoming elections in 2018, the article deliberates whether meaningful changes in the country's situation are possible in the nearest future and what it will take to achieve them.
\end{abstract}

\section{To understand the present, one has to know the past}

Undoubtedly, the history of a given country is inextricably linked to the people that govern it. Zimbabwe is quite unusual in this respect. From the moment it gained independence from the white rule until November 2017, Zimbabwe was practically governed by only one major political party - ZANU PF, led by Robert Gabriel Mugabe. His 37 year reign has left an irrefutable mark on the history of 
this country. At some point, in the late 1980s the World Bank and IMF forecasted Zimbabwe as one of the fastest developing economies of the SADC region, however in 2008 it registered in the world's history as the country with one of the greatest hyperinflation.

Mugabe is both a hero and a villain for the people of Zimbabwe. This may be the cause of the paradox that Zimbabwe could not prevent the destruction of the economy by the country's political leaders for so many years. Mugabe is seen as the liberation icon, he gave the education to the masses, and returned the land that rightfully belonged to them. On the other hand, he restricted people's freedom and created toxic relations with western countries and international community, which in turn led to sanctions. His policies led to an economic collapse and impoverishment of the people.

However, what went wrong in Zimbabwe is not just a doing of one man. It is a complex matter of colonial background, bad international relations, internal and external forces, race and land issue, among others. How could a country which everybody had big hopes for since its independence, backslided so badly in considerably short time? What follows tries to portray how Zimbabwe became what it is nowadays. An endeavor to clarify what turned out badly in Zimbabwe, following its freedom in 1980, requires a more drawn out chronical view and the cross-examination of a more broadcast of the economic, social, and corporate governance as a whole. Authentic progress for Zimbabwe might take a lot of years of effort, but it's important to remember that a country, which cannot learn from its history is doomed to repeat it. The chronological overview below provides a framework for a deeper analysis of the structural, historical and economic factors that affected the development of Zimbabwe.

\section{Pre-colonial times}

The country that we currently call Zimbabwe is the land between the Limpopo and Zambezi rivers, which from the late $19^{\text {th }}$ century to 1980 was called Southern Rhodesia or simply Rhodesia. It has an area of about $390245 \mathrm{~km}$ and borders Zambia to the north, Botswana to the west, Mozambique to the east and South Africa to the south. Using the study of Henryk Zins (2003, p. 11), we can conclude that despite high ethnic and linguistic homogeneity, the Shona population had never created a consistent and sustainable state organization. Over the years, different states were created, such as old Zimbabwe $\left(13^{\text {th }}-15^{\text {th }}\right.$ century), Torwa ( $15^{\text {th }}-17^{\text {th }}$ century), Mutapa ( $15^{\text {th }}-19^{\text {th }}$ century), Changamire $\left(18^{\text {th }}-19^{\text {th }}\right.$ century) and others. Trade on the Zimbabwean Highland included salt, cattle and ocher on a small scale, and gold, iron and copper on a larger scale, as well as slaves and ivory. This is confirmed by the existence of trade centers on the East African coast, 
such as Rhapta, Manda, Mogadish, Malindi, Mombasa, Kilwa and Sofala (Zins 2003, p. 17).

One of the oldest empires is the old Zimbabwe (circa $13^{\text {th }}-15^{\text {th }}$ centuries), which is evidenced by the ruins of a huge architectural structure called the Great Zimbabwe. For decades, there has been a dispute about the origin of this ruin. It was a subject of scientific and political controversy as well as the basis for speculation. Already by the $16^{\text {th }}$ century, the Portuguese who sailed along the coast of Africa contributed to the theory that Great Zimbabwe was proof of Middle Eastern influence, or even that it is a remnant of the biblical land of Ophir (Zins 2003, p. 20). In the $19^{\text {th }}$ century, Phoenicians, Jews, Persians, and Arabs were mentioned as possible creators of this object. Later, these views were eagerly promoted by the colonial authorities, because they supported theories of black inferiority; they would not have been able to create something so advanced. Such theories justified colonial rule in these areas (Davidson 1972, pp. 266-270). However, archaeological research leaves no doubt that the builders of the monumental Great Zimbabwe were in fact Shona people (Thompson 2003, p. 345 ). Its name comes from the Shona word dzimba dzamabwe, which means "house of stone". In the $15^{\text {th }}$ century, Great Zimbabwe lost its political and economic importance, probably due to the exhaustion of natural resources, as well as changes in trade routes.

After the fall of Great Zimbabwe, Mutapa became the main state. There are various Portuguese narratives about the Mutapa state, dated as far as $16^{\text {th }}$ century. The interest in Zimbabwean highland exploitation grew primarily because of the discovery of gold in these areas. The power of the Portuguese was expanding and at the end of the $16^{\text {th }}$ century they made a deal with the local ruler. He recognized the superior authority of the king of Portugal, which also resulted in Portuguese occupation of gold mines. The mid-seventeenth century was the most successful period in the history of Portuguese rule in Africa - about 16000 ounces of gold flowed annually through the settlers market from the Zimbabwean highland. It is difficult to specify to what extent Christianity contributed to the growth of European influence in those areas. At the end of the $17^{\text {th }}$ century, the Portuguese authorities began to fall under the influence of the resistance of the united local people (the Mutapa state established cooperation with Changamire one, among others). At the beginning of the $18^{\text {th }}$ century it was the Changamire state that came to the fore, and Mutapa lost its position.

Despite problems and weaknesses, the Mutapa state survived almost until the end of the $19^{\text {th }}$ century, when due to Portuguese expansion, the land was divided. The total partition of the former Mutapa state took place as a result of the British ultimatum of January 1890, which heralded unavoidable British colonial expansion. As the outcome of West Africa Conference held in Berlin in 1884-1885, the whole Africa was divided by European countries into 52 states. The whole

\footnotetext{
${ }^{1}$ From: Thompson 2003.
} 
Zimbabwean highland found itself under Great Britain's sphere of influence and at the end of the $19^{\text {th }}$ century it was transformed into British Rhodesia (Zins 2003, p. 39). Other formations from neighboring areas, such as Torwa or Changamire, were less important. In addition to the overpopulation of the areas, migratory movements of the population intensified, which in turn led to disturbances and fighting among African societies. In the $19^{\text {th }}$ century, the area of Changamire was taken over by the Ndebele population from the south of Africa. Despite the language differences, it became - along with the Shona population - the second most important ethnic group of the country.

\section{British colonialism}

The emergence of Rhodesia should be seen in the context of the rivalry of Great Britain, France and Germany for the influence, land and wealth of Southern Africa, in the name of new imperialism. The existing British settlement in Cape Cod made it easier for information about the discovery of gold on the Zimbabwean highland to cause a gold rush. Imperial traditions were an important element of identity for the white inhabitants of Rhodesia. The imperial ideal was closely related to their concept of their actions, formulated on a dual basis of racism and biological determinism. This development of political consciousness and the mentality of White Rhodesians led to considerable racial, social and moral conservatism emphasizing the value of capitalism (Zins 2003, pp. 203-204). In the initial phase of British expansion, King Lobengula was undoubtedly the central figure. Contrary to some views that he was a weak ruler and a bad politician, recent research emphasizes that he was in fact diplomatically talented. Yes, he granted British mining companies the privilege of seeking gold, including Limpopo Mining Company and South African Gold Fields Exploration Company. He allowed the London Missionary Society to set up mission stations, but at the same time did not let his subjects accept Christianity, which resulted in the failure of the missions among Ndebele people at that time. He maintained good relations with Europeans, wanting to draw on technical improvements, but did not allow for violation of the political and social structures of his people.

Central figure in colonial southern Africa was Cecil Rhodes, a businessman and politician who very quickly made a fortune on diamonds. He was the leading ideologist of British imperialism. The area of future Rhodesia would prove to be an ideal territory, fulfilling Rhodes' conditions for British expansion on the Black Continent - access to natural resources, communication routes and appropriate conditions for white settlement. In order to secure power, King Lobengula agreed to a deal with the British: the British would provide firearms, and in return the king granted Rhodes' company the exclusive right to exploit Matebeleland's mineral resources in 1888. In the same year Lobengula also signed the so-called Moffat's 
Treaty, in which he pledged to maintain a peaceful relationship with Great Britain and also not to engage in political treaties with other countries (Zins 2003, p. 81). Lobengula did not quite realize how much power he had given to the British, but it was too late. In 1889 the British South Africa Company was established, and by virtue of the general royal privilege received significant room to maneuver practically all of modern Zimbabwe and Zambia.

In 1890, the Pioneer Column (200 British settlers, 200 white police functionaries and several hundred Africans as side help) set up the city of Salisbury (today's Harare, the capital of Zimbabwe) and proclaimed the occupation of this part of the Zimbabwean highland. This occupation of Mashonaland took place almost bloodlessly. After a few years of seemingly conflict-free coexistence, the First Chimurenga war broke out in 1893 between the Ndebele people and their colonizers (in the local language chimurenga means "revolutionary struggle"). King Lobengula had 18000 warriors while the forces of the British South Africa Company numbered just over 3000 . However, the British were much better equipped. Lobengula was defeated and died shortly after. Regardless, his death was the end of Independence of Matabeleland and Mashonaland, and the British South Africa Company took complete control of this area, giving it the name of Rhodesia in 1895 (Zins 2003, p. 92). In 1896-1897, the local population repeatedly initiated uprisings, but they were all doomed to failure (Curtin 2003, p. 562²).

White occupation of the Zimbabwean highlands at the end of the $19^{\text {th }}$ century meant not only the loss of independence for the black population, but also changes in the concept of land ownership and its function in interpersonal relations. Land had no market value in African tradition. It was a gift of nature accessible to everyone, just like water, air or sunlight. It belonged to the whole community, not to individuals, and anybody could use it on equal terms. Until the arrival of Europeans in Africa, the land had not been the subject of dispute between the people and the ruler. Despite all that, the land played a great role in the system of racial segregation and the loss of freedom for Africans. The colonists unlawfully seized the best lands for themselves, and for the urban population they set up Gwai and Shangani reserves in the Tribal Trust Lands (Zins 2003, p. 179).

Some activities of the British South Africa Company have been criticized by the United Kingdom, but it has not withdrawn its colonial privileges, only limited them for financial reasons. The 1898 constitution of Southern Rhodesia stated the creation of structures directly responsible to the United Kingdom and the limitation of the Company's rights, as well as providing the white settlers with the right to vote. The most important issue for White Rhodesians was to obtain the status of a self-governing colony and acquire a so-called "responsible government". In the first years of Rhodesia's existence, there were no major contradictions between the interests of BSAC and the colonists, but in the course of time they began to

\footnotetext{
${ }^{2}$ From: Curtin 2003.
} 
gain strength. The death of Cecil Rhodes in 1902 contributed to political radicalization among white settlers. In 1912-1913, two political organizations were formed to fight for regime change: the Constitutional League and the Rhodesian League. However, the outbreak of the First World War put this matter aside. It was not until 1923 that Rhodesia freed itself from the administration of the BSAC and obtained the status of a self-governing British colony. The 1923 constitution gave the colony extensive internal autonomy, but foreign affairs remained in the hands of the British governor.

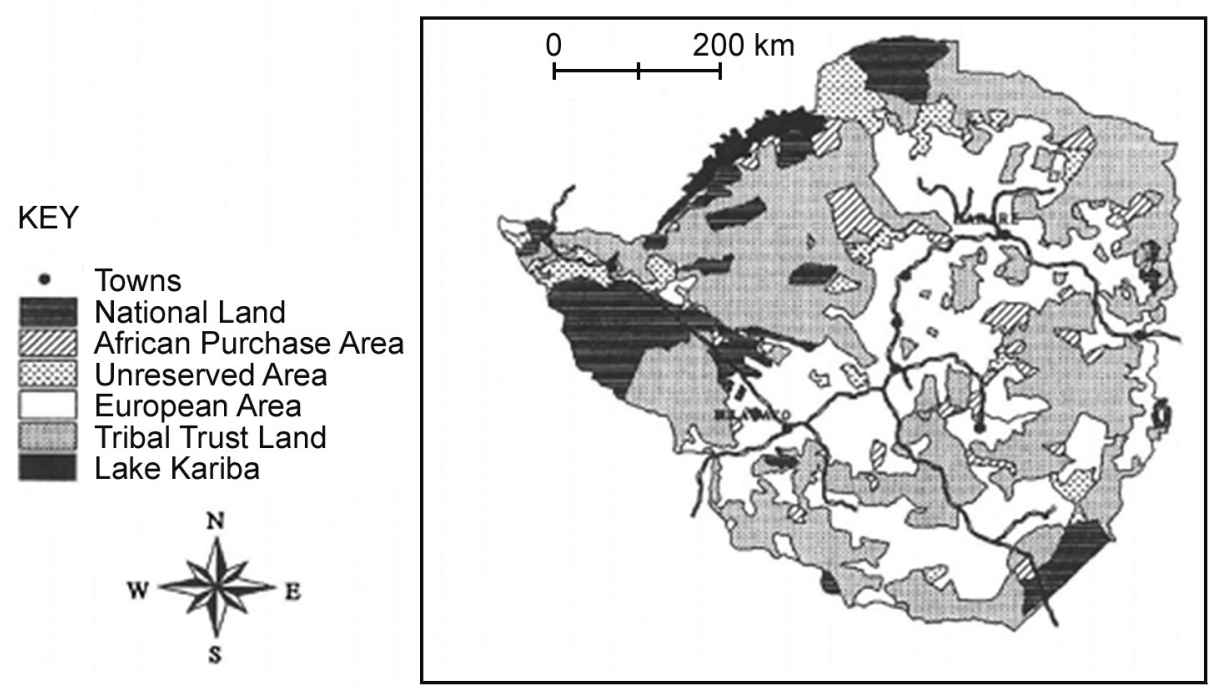

Figure 1. Rhodesian land apportionment, 1968

Source: Pwiti, Ndoro 1999.

African agriculture remained one of the key economic and political issues, and was an important element in the development of African nationalism in the $20^{\text {th }}$ century. The Land Apportionment Act of 1930 and Land Tenure Act of 1969 played a key role in regulating agrarian relations in South Rhodesia. The principle of complete segregation of races, their separate development and lives was then adopted. As seen on the map below (Figure 1), the land apportionment went as follows: Africans were allowed to acquire land, but only in designated African Purchase Areas forming a total area of 7 million acres. The second category of land distinguished in the Act was Unreserved Areas totaling 17 million acres, which the colonial administration could use depending on their needs. The third category was agricultural terrain for white settlers - 49 million acres of the best, the most fertile land in the country, with access to rivers. The fourth category was the Tribal Trust Land for the black population with a total of 21 million acres. All in all, Africans had only about $30 \%$ of their own country at their disposal (Zins 2003, pp. 183-184). In subsequent years, amendments were introduced to the Act, 
that worsened the situation of the local population even more, which led to the underdevelopment of the African economy and further impoverishment.

In the first years of its operation, the colonial government tried to solve numerous economic problems within the colony including the debt to Great Britain and relations with the Union of South Africa and Mozambique, through which $80-90 \%$ of Rhodesia's exports and imports were routed at that time (Zins 2003, p. 17). A lot of attention was also devoted to agriculture. In 1924, the Agricultural Bank of Southern Rhodesia was established, granting loans to farmers. In 1927 the Imperial Tobacco Company was founded, and later also the Rhodesian Tobacco Association. Thanks to good results, the country was included among the world's largest tobacco producers. In 1926, the Railway Commission was established, and in connection with the use of railways in the area of Southern Rhodesia, Northern Rhodesia (today's Zambia) and Nyasaland (today's Malawi), the concept of the federation returned. The federation was established as late as 1953, due to World War II, among other reasons, and existed till 1963 (Leśniewski 2000, p. 414).

In 1957-1959, the country's economic development stopped abruptly; there was a recession and a rise in unemployment. There had also been an increase in the national liberation movements of the African population. In 1957 the African National Congress, headed by Joshua Nkomo, was created. The rise of opposition in Southern Rhodesia led to the announcement of a state of emergency in 1959 (Oliver \& Atmore 2007, p. 307). After the outlawing of the ANC, the National Democratic Party was established in 1960, which was also forced to cease operations a year later in 1961. In response, the Zimbabwe African People's Union - ZAPU — was created, so the Federation's collapse seemed inevitable. Joining the struggle against the racist system, ZAPU established guerrilla troops collectively called the Zimbabwe Liberation Front. In 1962, parliamentary elections took place, during which Edgar Whitehead's government failed in favor of Rhodesia Front. Rhodesia Front, under the leadership of Winston Field and Ian Smith, was an extremist organization proclaiming the need to maintain ruthless racial segregation and white colonial supremacy (Leśniewski 2000, p. 415). Mass arrests of African activists were carried out and a great number of people were placed in prison camps. The next important event in the development of the liberation movement was the 1963 establishment of the Zimbabwe African Nation Union - ZANU - a more radical branch of ZAPU. This split initiated fierce rivalry between ZAPU and ZANU lasting until 1988, although in fact they fought for the same cause (Zins 2003, p. 132). An incident in July 1964, when a white farmer was killed by a so-called "Crocodile Gang" can be perceived as the beginning of civil war (Ginifer 1995, p. 7). This period of liberation fights, resulting in independence, is sometimes called a Second Chimurenga. 


\section{Unilateral Declaration of Independence from Great Britain}

In 1963, the United Kingdom dissolved the Central African Federation, and a year later it granted independence to its protectorates; changing Northern Rhodesia into Zambia and Nyasa into Malawi. A similar solution could not be applied to Southern Rhodesia due to the racist policy of Ian Smith's government and its rebellion, and the prior announcement of Unilateral Declaration of Independence UDI, on November 11 th 1965 (Leśniewski 2000, p. 416). Great Britain opposed this turn. The British Prime Minister, Harold Wilson, proposed a five-point plan to solve the Southern Rhodesia issue. It proclaimed that Africans would be granted $1 / 3$ of the seats in Parliament, the abolishment of discriminatory acts against the black population, implement of a widespread educational system and future pursuit of majority rule. However, the government of Rhodesia rejected this plan, the UDI met with only formal opposition from the United Kingdom, and no radical steps were taken. This way, the African people's fight for political rights was doomed to fail for over a dozen more years. The United Kingdom undertook political and economic actions by introducing sanctions. It is worth adding that not a single country in the world officially recognized the UDI (Oliver \& Atmore 2007, p. 317). The United Nations and all other nations continued to treat Rhodesia as a British colony. On one hand, the United Kingdom imposed sanctions, which included prohibiting the import of arms and capital, cutting oil supplies, and stopping imports of tobacco and sugar and other products. On the other hand, it never completely withdrew from Rhodesia, maintaining indirect contact. The UN and the Organization of African Unity demanded intervention (Zins 2003, p. 141). Rhodesia continued foreign trade, through South Africa and Portuguese Mozambique, avoiding strong effects from these sanctions.

The radical policy of the Rhodesian Front and the sanctions applied to it contributed only to a greater consolidation of the white minority and the strengthening of it. The irreconcilable government of Ian Smith rejected any compromise postulates of Great Britain, and therefore the British authorities announced the famous declaration of NIBMAR — No Independence Before Majority Rule in 1966. During the talks between the Rhodesian and British governments, the African liberation movement revived, but the guerrilla units were defeated in both 1967 and 1968. Alternatively, in 1969, the Rhodesian government passed a new constitution that introduced the republic regime. It also introduced the Land Tenure Act. Both of these documents were clearly racist. The Land Tenure Law provided for the division of the arable land of the country into two "equal" sections: 45 million acres for 5 million Africans and 45 million acres for 200 thousand members of the white population (Zins 2003, p. 147). 
After the republic was announced, the government of Ian Smith organized the first election in April 1970, and Clifford Dupont became the first President of Rhodesia, confirming the broad support of whites for the Rhodesian Front. The Rhodesian government did not officially banish Africans from political life, but by setting up an electoral census, which meant a requirement of good English knowledge and possession of a particular property, they excluded blacks from voting for a long period (Zins 2003, p. 177). The protests of Africans against this state of affairs were strangled under the pretext of combating terrorism. The main liberation parties, ZANU and ZAPU remained in constant conflict despite the appeal of the OAU for the creation of a unified front to fight against the government of Ian Smith. It was not until 1971 that the ultimatum of the president of Zambia, Kenneth Kaunda, who provided political and material assistance to both parties, led to creation of a united liberation organization - Front of the Liberation of Zimbabwe - FROLIZI. In reality, however, the division between conflicted ZANU and ZAPU further deepened, indicating the disintegration of the African liberation movement in Rhodesia in the early seventies

After the conservative party in the UK came to power, consultations on the future of Rhodesia resumed. On November $24^{\text {th }}, 1971$, the Salisbury Treaty was signed, which meant the end of the Rhodesian-British conflict. This arrangement was another success of Ian Smith's government in the fight for recognition of the legality of the white racists regime (Zins 2003, p. 151). The leaders of the liberation movements: Sithole (ZANU), Nkomo (ZAPU) and Siwela (FROLIZI), all strongly condemned the Salisbury Treaty as harmful to Africans and omitting them completely from the process. Therefore, the armed struggle continued. In 1972, based on the report of a special commission, it was announced that due to the negative reactions of most Africans to the Salisbury Treaty, the United Kingdom would maintain sanctions against Rhodesia (Leśniewski 2000, p. 420). Within a few years, due to the changes in the governments of Portugal and Great Britain, the position of racist Rhodesia was weakened and in 1974 in Lusaka an attempt was made to work out a compromise between the government of Ian Smith and the parties of the liberation movement. This failed, but at last, four African liberation parties: ZAPU, ZANU, FROLIZI and ANC (African National Council) had embarked on a united front. The guerrilla warfare intensified, supported by countries such as Tanzania, Zambia, Botswana, Angola and Mozambique, as well as increased aid from the USSR and other socialist countries. Even though ZANU and ZAPU had by the late 1970s "transcended in some respects the earlier strategy and tactics of the 1960s which saw violence as merely the means to pressure Britain into an intervention that would bring Independence sooner rather than later", armed conflict was still "at best, viewed as a means to dismantle the white settler colonial system and replace it with an African government and, at worst, as a pronounced way of pressurizing the imperialists into convening a conference that would bring about an African government in Zimbabwe" (Mandaza 1986, 
p. $\left.29^{3}\right)$. Then, in 1976, the leadership of ZANU was assumed by the key figure on the political scene, who would be so important in the coming fight for independence - Robert Mugabe.

Since 1976, Smith's government had been under heavy pressure from the Western powers, especially Great Britain and the United States, which sought to ensure that African politicians would rule in independent Zimbabwe. What was more important, they ought to be pro-western. Because of this pressure, a conference on the future of Zimbabwe took place in that year in Geneva. The parties were: the British delegation, the Rhodesian delegation and representatives from four liberation parties. Once again, no agreement was reached. The first public compromise between the leaders of the white minority and those of some African parties - Muzorewa, Sithole, and Chirau - was the Internal Settlement signed in March 1978 (Oliver \& Atmore 2007, p. 319). However, it met with criticism from the Patriotic Front of Zimbabwe, which was an organization formed by Nkomo and Mugabe, and thus a mix of ZANU and ZAPU (Zins 2003, pp. 59-160). It was only a tactical alliance, not a unified body proclaiming common goals. In fact, the Internal Settlement was supported neither internationally nor internally and it was even condemned by the UN (Ginifer 1995, p. 9).

The African National Council and the United Nations had also expressed their disapproval and appealed to Great Britain to take all necessary steps to liquefy the illegal regime of Salisbury and bring the process of decolonization of Rhodesia under full compliance with UN resolutions. The guerrilla activity intensified, led by Mugabe and Nkomo. Therefore, in September 1978 Rhodesia announced martial law. After the weakening of the leading liberation parties - ZANU-Mugabe and ZAPU — in April 1979, general elections took place, and as a result the new government was established. Muzorewa became the prime minister and Josiah Gumedy became the first president of the newly founded Zimbabwe-Rhodesia. However, this solution did not find wider approval in the international arena and was considered unjust and temporary (Zins 2003, p. 165). At the conference of the member states of the British Commonwealth in Lusaka, the elections from April were declared corrupt, and the United Kingdom admitted that its constitutional duty was to grant independence to Zimbabwe and that it fully realized the urgent need to bring peace to this part of Africa.

\section{Fully independent Zimbabwe - politics}

On September $10^{\text {th }}, 1979$, a constitutional conference took place in Lancaster House in London. The parties were, among others: the British Foreign Minister Carrington, Smith and Muzorewa on the part of the Rhodesian Government, and Nkomo and Mugabe as the representatives of the Patriotic Front of Zimbabwe.

\footnotetext{
${ }^{3}$ From article The state politics of the post-white settler colonial situation.
} 
It was an important event for the future of the country. The conference lasted 14 weeks and ended on December 21 $1^{\text {st }}, 1979$ with the signing of an agreement that closed the period of colonialism and defined the conditions for the creation of a new, independent Zimbabwe. Those general principles were:

- unimpeded progress to majority rule must be maintained and guaranteed; tution;

- there must be guarantee against retrogressive amendments to the consti-

— there must be an immediate improvement in the political status of the black population;

- there must be progress towards ending racial discrimination;

- the constitutional proposals must be acceptable to the people of Rhodesia as a whole;

- there must be no oppression of the majority by the minority or of the minority by the majority (Lancaster House Agreement Report 1979).

According to the Lancaster Agreement, the country underwent a demilitarization process, which was supervised by Commonwealth Force Monitors - CMF. This operation differed in various respects from similar United Nations demilitarization actions, and its methods were perceived as controversial. First of all, CMF did not carry out the disarmament, the parties were still in possession of weapons, although their use was limited. Secondly, the UN was deliberately excluded from the process, which resulted in CMF being unilaterally managed by the British. What's more, only minimal forces were used - 1319 monitors (Ginifer 1995, p. 4).

The first democratic elections were scheduled for February 1980, and the British Governor, Lord Soames, became the interim governor. He guarded the order in the pre-election period, full of clashes between the parties and attacks on political opponents. The elections were conducted under the supervision of nearly 200 observers from 20 countries. The turnout amounted to $92 \%$ of the population. The elections showed a clear advantage for the party of Robert Mugabe ZANU, and he became the first elected prime minister of independent Zimbabwe. In April 1980, the last events closing the long period of the Africans' struggle for liberation took place. On February 18, Canaan Banana was sworn in as the first president of Zimbabwe, and thus the country finally ceased to be a colony of Great Britain (Zins 2003, p. 174).

The newly independent government of Zimbabwe has inherited a paradox. As Seidman says:

Zimbabwe enjoys one of the highest average per capita incomes in Sub-Saharan Africa, but the majority of its population remains among the most impoverished in the world. Indeed almost a century of colonial capitalist rule has left Zimbabwe with several contradictory characteristics. (Seidman 1982, p. 130)

When Prime Minister Robert Mugabe took office in 1980, he faced a difficult task. He, a universally educated politician, and a Marxist, was to manage the state of 
a colonial-type capitalist economy. For a long time, white people had an economic advantage over the black population. Key positions in the economy, administration, culture, army and police were occupied by whites. An additional problem was the differences between Shona and Ndebele peoples as well as internal conflicts in the two main parties - ZANU-PF and PF-ZAPU. Mugabe made a promising start, he proclaimed the need for reconciliation in his first speech as prime minister, appealing for unity and cooperation for the sake of independent Zimbabwe. However, even within his ZANU-PF, he had to face groups supporting more radical changes, among others targeting the white population. Mugabe, on the other hand, had chosen a pragmatic, balanced policy, based on the capital, technology and expertise of white Zimbabweans. In his philosophy he supported the idea of building a multicultural society (Zins 2003, p. 251). During the first decade of Mugabe's rule, there were some major improvements in social services, especially in education and healthcare system. For example, a research conducted by SARIPS 4 in Harare showed that health expenditure was Z\$18,17 per capita in 1990/1991, whereas in $1979 / 1980$ it was Z\$8,19. During the same period, education expenditure almost tripled from $Z \$ 10,61$ to $Z \$ 28,70$. What is more, primary education became free and compulsory, which allowed children from rural and poor families to learn, resulting in substantial improvement in literacy level. Infant mortality rate decreased from 88 to 61 per 1000 births and children immunization elevated from $25 \%$ to more than 85\% (Gowland 2002, pp. 30-31). Mugabe's diplomatic talents were recognized internationally in the 1980s. He was the chairman of the movement of non-aligned countries, and on a large scale developed activities for peace, freedom of the country and the fight against racism (Zins 2003, p. 262).

In Southern Rhodesia, there was a clear division of the traditional and old-fashioned economy of Africans and the modern production of white settlers. Independent Zimbabwe inherited a well-developed economy by African standards. Paradoxically, international sanctions imposed during the time of the existence of Rhodesia contributed to the development of country's own production, making it self-sufficient to a large extent. Sanctions had been a stimulus for the development of industry and mining. Despite the efforts of the independent government, agriculture has for a long time retained many features of the colonial period. Products from large white-owned farms, including tobacco, provided Zimbabwe with a significant part of its national income. However, the agriculture of the local population remained very outdated. Robert Mugabe's government understood that white farming was the foundation of the Zimbabwean economy. In the early 1980s, white commodity farming accounted for $95 \%$ of the total agricultural production of Zimbabwe, and African agriculture only 5\% (Zins 2003, p. 273). The same was true for mining, where over $80 \%$ was in the hands of Western companies.

\footnotetext{
${ }^{4}$ Southern African Regional Institute for Policy Studies.
} 
In the field of agriculture, Mugabe saw the need to maintain the division of three sectors: large, highly commercial plantations (mainly owned by whites), smaller African farms and small peasant activities. He postulated a gradual process of change and believed in the evolutionary nature of socio-economic transformations, as well as political ones. Even back then, he had already started introducing the idea of a one-party system. Mugabe encountered resistance from Joshua Nkomo, who hoped that his party PF-ZAPU would still gain a leading position in the country. There were suspicions that he was planning to take over power with the help of external forces, including South Africa, and collaborating with Ian Smith. Nkomo claimed that his party PF-ZAPU was being harassed by the Mugabe government, although both parties had fought side by side for independence. To prevent conflict, Mugabe went to a meeting with 176 leaders of Matabeleland, where he stressed that in a country that strives for unification and development, there is room for only one government. This was an allusion to Nkomo's efforts to build his own political base. However, at the same time, nine PF-ZAPU leaders were arrested, and riots broke out in Bulawayo, during which 58 people died and over 500 were injured (Zins 2003, p. 255). Further crisis was averted thanks to the joint meeting of ZANU-PF and PF-ZAPU and an increase of the representatives from PF-ZAPU in the Zimbabwean government. Later, however, Nkomo removed himself from the political scene in connection with charges of attempts to overthrow the government. What is more, a large amount of undisclosed weapons from the Soviet Union and the Republic of China were found on the farms belonging to PF-ZAPU. After the disclosure of these allegations, Nkomo and several other ministers were expelled from the government. Gradually, by demonstrating the disloyalty of PF-ZAPU leaders and their collaboration with the countries of the USSR, the People's Republic of China and South Africa, Mugabe weakened the opposition and won the support of some of the PF-ZAPU leadership. In 1983, Nkomo decided to flee to Botswana and then to London. Many other ZAPU members returned to Matabeleland. Mugabe accused the local population of taking action to overthrow his rule. In January 1983 he sent troops to the suspected areas. There were reports of mass murder, beatings, torture, arrests, cutting off food supplies - not only among the dissidents, but also civilians. Over a few years, at least 10,000 people were killed (The Choices Program 2009, p. 4).

Conflict and violence, at least in an official form, were averted at the end of 1987, when the two opposing parties came together and Zimbabwe became a state with a one-party system. It is believed that Mugabe, under the cover of the fight against dissenters, used this fact to defeat the rival party. Therefore, the process of forming a united state did not occur without internal struggles for political rights and privileges. It is worth mentioning that Mugabe's government never took responsibility for the violence that took place in Matabeleland. That same year, 1987, the government amended the constitution, withdrawing the role of a prime minister. Mugabe became an executive president, gaining even more power. The 
next elections in 1995 provided ZANU-PF with a continuation of power, although this was not without stimulating policies against white farmers and displacing them, regardless of their contribution to the economic development of Zimbabwe. ZANU-PF consolidated its economic power; the units closest to Mugabe used their position to secure the best business opportunities. Corruption, bribery and theft were common - among other crimes; in 1990/1991, ministers and members of the parliament received a salary increase of $133 \%$, while healthcare and education expenditure were reduced by 43\% (The Choices Program, 2009, 4). By 1992 school enrollment decreased by $7,5 \%$, spending for schools fell by $32 \%$, children malnutrition was elevated by $13 \%$. Inflation increased from $23 \%$ in 1991 to $46 \%$ by the end of 1998 and real waged fell by 33\% between 1990 and 1997. Furthermore, between 1991 and 1995 private sector reduced 25510 workers and public sector 20000 . With more young people leaving school and less working places, the situation worsened - during 1990s each year about 300000 school-leavers joined the labor market. The poverty was expanding — according to the Zimbabwe Development Report from 1998, 61\% of Zimbabwean household were poor, and $45 \%$ of there were very poor. In 1990 the Economic Structural Adjustment Programme was introduced, that featured World Bank and IMF economic reform strategies, but it didn't bring sufficient results (Gowland 2002, pp. 33-34). Additionally, in 1997, the government under pressure from independence war veterans payed \$50 000 to each war vet (Bertelsmann Stiftung 2018, p. 6).

In 2000, Mugabe's government faced its first major political defeat when the proposed changes to the constitution were widely rejected in the referendum. These amendments would have given the government additional privileges and allowed Mugabe to apply for the next two presidential terms. In addition to the rejection of the new constitution, Mugabe's government faced a new challenge - a growing opposition. In the 2000 parliamentary elections, the Movement for Democratic Change (MDC) - an opposition party formed in 1999 and headed by Morgan Tsvangirai - won a record number of seats, and in the presidential election, Tsvangirai was a strong opponent to Mugabe (The Choices Program 2009, p. 7). Many independent observers have claimed that violence and intimidation of voters had intensified at that time. The government controlled the media, publicly criticizing the MDC and accusing its members of being British puppets. As published in an article in The Economist before the presidential election in 2002, such tactics have worked before:

[a]t independence in 1980, Mr Mugabe would have won a fair vote. But just to make sure, the more thuggish members of his party, ZANU-PF, prevented opposition supporters from campaigning in a third of the country. In the mid-1980s, fearing that the Ndebele tribe might someday thwart him, he murdered at least 10,000 of them and forced survivors to dance on their brothers' graves singing ZANU anthems. By 2000, ZANU's popularity had plunged, and the party would certainly have lost its majority in parliament if Mr Mugabe's hired hoodlums had not burned down thousands of peasants' homes and threatened to come back and kill them if they elected an opposition candidate. (The Economist 21.02.2002) 
Despite many reports of electoral fraud, Mugabe won another six-year term.

In 2005, the government carried out a program aimed at slum towns, called Murambatsvina, which in Shona means "to restore order". The government claimed that the program fought crime and illegal traders. On the other hand, MDC claimed that the people most affected by this program were the poor, who happened to be MDC's electorate. The MDC therefore saw it as a punishment, a vindictive act against the opposition.

In 2008, the MDC was truly close to winning the elections. In the parliamentary election, for the first time in the history, they won the majority of seats in the House of Assembly ${ }^{5}$. The presidential election aroused even more controversy. The government delayed the results of the first round, trying at all costs to falsify them. Finally, after more than a month, it was announced that Mugabe won $42 \%$, and Tsvangirai $48 \%$ of the votes. Therefore, the second round was in order. In the weeks leading up to the final elections, violence and intimidation intensified, especially for members of the MDC and their voters. About 200 people died (The Choices Program 2009, p. 9). Shortly before the election, Tsvangirai withdrew. He did not want to expose people who supported him to further repression. Ultimately, Mugabe won the election with $85 \%$ of the vote. The international community did not recognize these elections and Mugabe, under the pressure of neighboring countries, agreed to negotiate for the purpose of creating a power-sharing government. The arrangements lasted several months, but finally, in February 2009, an agreement was obtained. Mugabe was sworn in once again as president, Tsvangirai served as prime minister, and government positions were divided among ZANU-PF and MDC members.

\section{The issue of land reform}

The land reform in Zimbabwe officially began in 1980, when the Lancaster House Agreement was signed. It intended to distribute the land fairly between black farmers and white Zimbabweans of European ancestry. The objectives of the program were to change the ethnic balance of land ownership. Colonial policy had left negative consequences, which were and still are one of the major challenges for the political and economic development of former colony countries. The basis of settlers agricultural policy was large-scale farms. Before the fast-track reform program in Zimbabwe in 2000s, there was still clear disproportion and injustice regarding land rights: 4500 white farmers were in possession of 11 million hectares of the best, fertile lands, and 1 million black people had about 16 million hectares (Peters 2003, p. 343). Such agrarian reform is quite a challenge, especially in these countries, where traditional power structures are defined by land and natural

5 Similar to Great Britain legislature, Zimbabwe's parliament is made up of a Senate and a House of Assembly. 
resources. In an era of democratic reform, declaring lands as private or state property often complicates matters of decentralization and ultimately, control over the economy. These reasons, as well as the conditions of the Lancaster House Agreement, delayed agricultural reform in Zimbabwe for several years after independence. According to the Act, Great Britain made a commitment to compensate the white farmers for their lands on the 'willing seller, willing buyer' basis. However, the Act also stated that for the first decade, the Zimbabwean government could not force farmers to give away their land. Another factor was corruption and political issues that halted subsidies from the United Kingdom. The Lancaster House Agreement didn't provide a specific amount to be used to implement the land reform. The country had donated about 44 million pounds to Zimbabwe in 1980, but in 1996 it withdrew part of the subsidy, as the funds had never been fully used. Additionally, in 1997 when New Labor party, headed by Tony Blair, came in, they unilaterally broke of the agreement (Peters 2003, p. 344).

In 1990, the government introduced an amendment to the constitution which sanctioned the take-over of lands belonging to white farmers at fixed prices. As Mugabe said himself when he addressed the ZANU-PF Central Committee meeting in 1993:

If white settlers just took the land from us without paying for it, we can in a similar way just take it from them, without paying for it, or entertaining any ideas of legality and constitutionality. (Mugabe 7.09.1993)

Many of the farms taken over in the 1990s went to ministers and other officers, chosen on the basis of their connection with the president. Part of the land actually went to people who were in need, but they were not prepared and received almost no support to continue agricultural production (The Choices Program 2009, p. 6). Mugabe's government used agricultural reform as a political tool to achieve its goals and maintain its power, eventually carrying out organized invasions of white farms starting in February 2000. Sam Moyo, the head of the African Institute for Agrarian Studies in Harare said that the land redistribution was "broad-based and largely egalitarian". He stated that more than $2 / 3$ of the land taken since 2000 was allocated to 140000 poor families, but he also admits that around $30 \%$ of land went to 15500 army officers, security services, ministers, judges and parliament members (The Economist 5.03.2009).

The fast-track agricultural reform carried out in Zimbabwe had an impact on nearby states. The number of foreign investments fell, probably because of concerns about the security of such investments (e.g. in Malawi). Other countries that were affected by land reform in Zimbabwe were Namibia and Mozambique. In 1990, Namibia began to implement an agrarian reform program that was designed to give ordinary people the opportunity to own land. The resettled people received the land for a 99 year lease and the official ownership remained in the hands of the state. The government planned to redistribute 9.5 million hectares of land (Peters 
2003, p. 345). On the other hand, the 1997 land reform in Mozambique was revolutionary in terms of the combination of formal and customary law. Thanks to that, control over the land passed from the officials to common family structures. Their law says that someone who has occupied a piece of land "in good faith" for over 10 years has legitimate claims to it. Moreover, although the land in the country officially belongs to the state that leases it to individual units and enterprises for 50-99 year terms, traditional leaders have the opportunity to give land to their subjects (Peters 2003, p. 347). When the Zimbabwean government chased off white farmers from their country by occupying their farms, the Mozambique government invited these farmers, offering them 50 year leases and thus contributing to the development of the agricultural sector (Peters 2003, p. 348).

Organized raids, fast-track agricultural reform policy and previous allegations of corruption and mismanagement led to internal opposition to Mugabe's government. At the same time, almost nobody criticized the need for change in land rights for the local population (Peters 2003, p. 344). There is no doubt that the people who were exploited during the period of colonialism were hungry for the land that belonged to them. Unfortunately, such a policy of change and invasions of farms caused a decrease in agricultural production. It was not enough for its own domestic production and the country had to start relying on imported food and help from other countries. Apart from white farmers, the invasion was also aimed at members of the MDC. According to The Economist

2,900 white farmers, whose farms have been earmarked to be seized and given to blacks, were legally obliged to cease work. Those who continue to plough, weed and scatter seeds face jail terms of up to two years. (The Economist 27.06.2002).

The government allowed the farmers to stay for 45 days and to take their valuables when they left, but in fact police at roadblocks stripped them of almost everything (The Economist 27.06.2002).

\section{Prelude of economic crisis and the end of Mugabe's era}

In the years 1931-1965 the country was a part of the sterling area and in 1965 Ian Smith's government replaced the Rhodesian pound with the Rhodesian dollar. At the time of independence, the value of Zimbabwe's dollar was equal to USD \$1,47 and it was tied to a flexible basket of currencies. In 1994, the independent float replaced the flexible basket and in years 1999-2009 Z\$ was attached to USD (Noko 2011, p. 341). Noko describes two main events that led to country's financial problems. The first was the decision of the government to help with the Second Congo War and the cost this four-year war brought. The second was the land expropriation program that resulted in the plunge of farms productivity by half in years 2000-2007 and the 
decrease of direct foreign investments from USD \$400 million to USD \$30 million (1998-2007). What is more, sanctions from UK, USA and EU and the withdrawal of support from International Monetary Fund also played a role in the process.

By 2003, the value of $Z \$$ was lower than the cost of printing it. The government started issuing bearer checks with high denominations, which circulated in the system up until 2009. Then, the policies of certain banks led to a liquidity crunch that cost the banking system approximately $\mathrm{Z} \$ 2$ trillion. To combat food shortages and price speculations, the government froze prices for few months in 2007, but the situation worsened. The Z\$ was devalued in April 2006, then again in September 2007 and again in August 2008 (Noko 2011, p. 344). The Reserve Bank continued printing money, it seemed as if it wanted to defy the rules of economics. Gideon Gono, then governor of the Reserve Bank of Zimbabwe, claimed that "traditional economics do not fully apply in this country," and said "I am going to print and print and sign the money... because we need money" (The Economist 12.05.2016). Zimbabwe fell into hyperinflation reaching an annual rate of 90-sextillion \% in November 2008 (Bertelsmann Stiftung 2016, p. 19).

The new unity government that came into power after the 2008 elections, introduced a Short-Term Economic Recovery Program and decided to fully dollarize Zimbabwe, though it never entered any official agreement. USD was adopted as the primary currency, but few other currencies like rand, euro and metical were also in use. In this way, a new multi-currency regime was implied (Noko 2011, p. 349). Dollarization had a great impact on inflation rates, ensured monetary stability and increased credibility for investors.

The power-sharing agreement lasted until 2013, when another election took place. Its results were widely contested, again there were reports of voter intimidation and complaints regarding how elections were held by the Zimbabwe Electoral Commission. Nonetheless, observers from SADC claimed the elections were free and generally credible (Bertelsmann Stiftung 2016, p. 7). As a result, Mugabe and his party ZANU-PF returned to one-party rule over Zimbabwe. In the following years, voices were raised on the topic of the lack of a successor to Mugabe. People within and outside of the party started to question what the post Mugabe era would look like. His ruthless control of the party started slipping.

In November 2017 Zimbabwe entered a new chapter, when Robert Mugabe was removed from power by the military. On the $15^{\text {th }}$ of November Major-General Sibusiso Moyo appeared on television saying:

Firstly, we wish to assure the nation that his Excellency, the President, of the Republic of Zimbabwe, Head of State and Government and Commander in Chief of the Zimbabwe Defense Forces, Robert Mugabe and his family are safe and sound and their security is guaranteed [...]. We are only targeting criminals around him who are committing crimes that are causing social and economic suffering in the country in order to bring them to justice. (Barnes 15.11.2017) 
He also reassured citizens that:

[t]o both our people and the world beyond our borders, we wish to make it abundantly clear that this is not a military takeover of government. What the Zimbabwe Defense Forces is doing is to pacify a degenerating political, social and economic situation in our country which if not addressed may result in violent conflict. (Barnes 15.11.2017)

Mugabe was given few days to resign. At first, he refused, but he eventually stepped down, when the Parliament started the impeachment process.

What led to the coup was that Mugabe's second wife, Grace, 41 years younger than him, seemed to seek to inherit leadership in Zimbabwe. "Power is not sexually transmitted" 6 - became a popular slogan at that time. For years Grace remained in the shadow of her husband, but in the meantime her shopping sprees earned her the title of "The First Shopper" and "Gucci Grace". With time, her ambition increased and she invested more effort into politics and even formed a group around her called Generation 40. Standing in her way to the throne was Emmerson Mnangagwa, 75 year old member of ZANU-PF, who had been on the political stage since Zimbabwe's fights for independence (IRIN 13.11.2017). Grace influenced her advanced in age husband to dismiss Mnangagwa. That triggered the reaction of the military, that does not trust anybody who is not a veteran of the liberation struggle.

In reaction to Mugabe's resignation, people went to the street, they were dancing and singing, celebrations went on and on. Then the question emerged - who will be the leader now? Mugabe was replaced with Emmerson Mnangagwa as a president of ZANU-PF and hence, the president of the party. Known as "the Crocodile", this former guerrilla fighter, who had just returned from his short exile, held several ministerial positions in Mugabe's government, among which were security minister and justice minister, and after 2014 he was Vice President of Zimbabwe until his aforementioned dismissal. Is he to be trusted? He promised fair elections, re-establishment of property rights, amendment of the indigenization law ${ }^{7}$ and many others. Many people hoped that he will introduce changes to his cabinet, but instead, he kept a lot of former ministers and party members. What is more, he appointed few of the positions to military - among which, general Constantino Chiwenga, who led the coup, became the vice-president (The Economist 1.03.2018).

"It was truly a military takeover. We must undo this disgrace" - these were Mugabe's words in his first TV interview as a former president. He claimed that his ousting has to be seen as a coup d'état and that Emmerson Mnangagwa is illegally in power. What can be surprising, given his own past, he said that it's important that a president is legally chosen by people and that Mnangagwa betrayed the whole nation

6 The words attributed to a war veteran, Jabulani Sibanda. In the time on the coup, it became a popular slogan against the possibility of Grace Mugabe inheriting the leadership in Zimbabwe.

7 Indigenization and Economic Empowerment Act from 2008 required all the businesses in the country to be at least $51 \%$ owned by Zimbabweans or the state - that in turn led to decrease in foreign investments. 
by not being democratic. The old man denied that his economic mismanagement led to the country's ruin. "Ruined? Of course no. If anyone compares... there is greater prosperity. People have their land" — he claimed (The Guardian 15.03.2018).

\section{Key indicators - a brief country report}

Thanks to the data collected by BTI, we are able to analyze the situation of the Zimbabwe, based on key economic indicators. The population of Zimbabwe was gradually growing in the course of years. Compared to the number given in a country study from 1979 (Simons 1979) - 7 million people — it more than doubled. The factors that led to a decrease in population in years 2008/2009 were: economic crisis, cholera outbreak and migrations, among others. Life expectancy elevated and is now at more than 60 years. During the peak of crisis, it dropped to as low as 37 years. In 1979 life expectancy for an African person was 50 and for a European - 72 years. This differentiation was caused by separate standards of living and healthcare for whites and blacks during colonial rule. The social gap between less numerous upper class and sizeable group of poor people still exist. The richest $10 \%$ of the population gets $40 \%$ of the national income and the poorest $10 \%$ only $2 \%$ of this income. This inequity was perceived as racially based for a long time. However, since the liberation from colonial rule, a lot of black Zimbabweans, especially in political and military structures, have made their way to the upper class (Bertelsmann Stiftung 2016, p. 8).

Zimbabwe has serious external and public debts. As of the end of 2016, Zimbabwe's public debt amounted US $\$ 11.2$ billion or almost $70 \%$ of GDP, of which the better part is external debt, primarily in arrears. Consequently, it led to the deterioration of relations with creditors. Since 2009, after the hyperinflation peak and as a result of taken actions, the inflation rate dropped to single-digit numbers. In a period of 2013-2016, Zimbabwe implemented a staff-monitored program, that addressed the reforms of central bank and financial sector, as well as exchange and monetary policies. Despite that, even up to now, Zimbabwe's banking system still suffers from chronic cash shortages. The liquidity is low and depositors have difficulties in accessing money, because of withdrawal limitations. In March 2016 The Reserve Bank of Zimbabwe introduced "bond notes", that were meant to help with the liquidity.

Zimbabwe's Human Development Index places the country in "Low Human Development" group, which shows that there is still a lot to be done, when it comes to key dimensions of human development, as measured by the index: a long and healthy life, decent standard of living, access to knowledge and expected years of schooling. In 2016, the World Bank showed that 72\% of Zimbabwe's population is living for less than US\$1.25 per day, which is the national poverty line. There is very little data regarding unemployment in this country, it's estimated between $60 \%$ and up to $95 \%$. This may be due to a large informal sector, that is still expanding (Bertelsmann Stiftung 2018). 


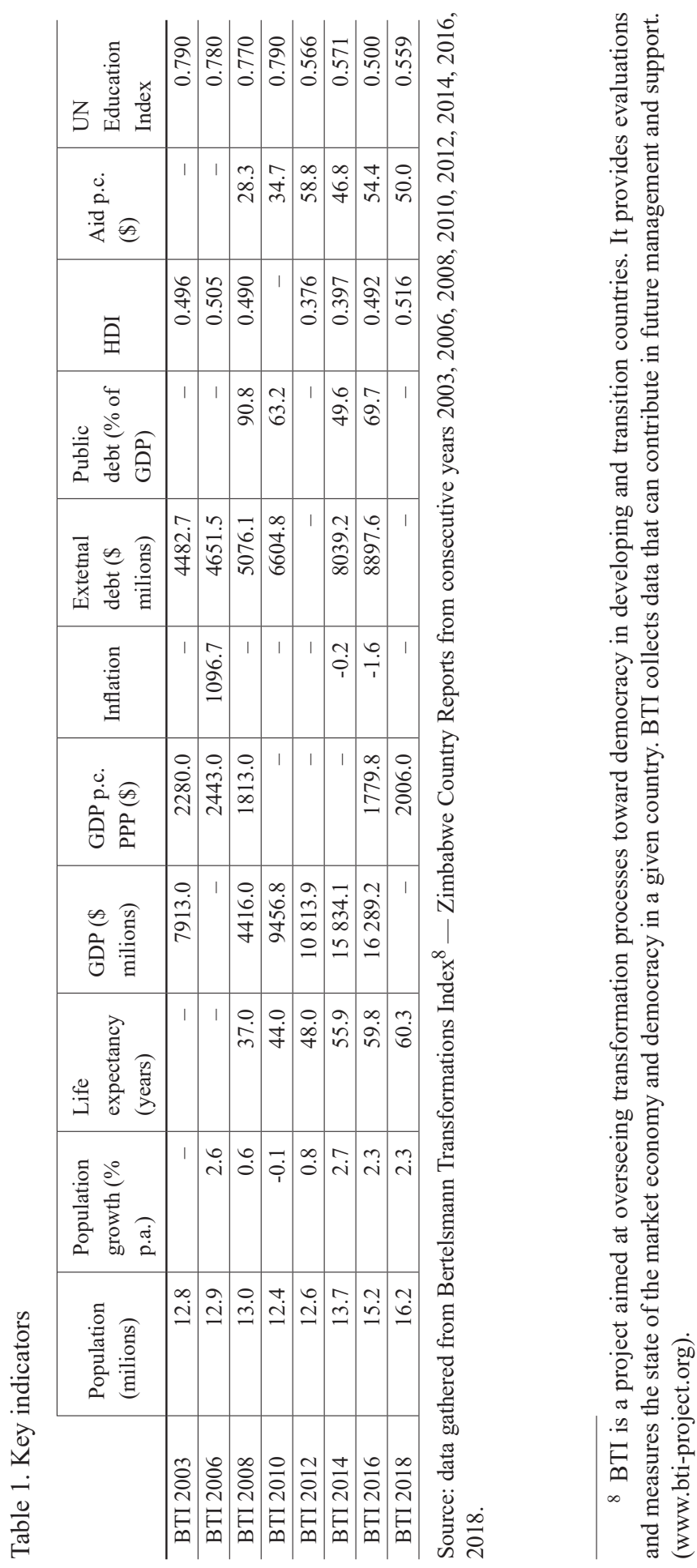

Ekonomia - Wroclaw Economic Review 24/1 (2018) (C) for this edition by CNS 


\section{A quest to move the country forward}

As the article shows, current situation in Zimbabwe is an outcome of several structural, historical and economic factors, starting with: colonial past, that affected the country on many levels; political regime that prevented true democracy and resulted in unfavorable international relations; and redistribution of land, which hasn't proceeded smoothly. The past shaped Zimbabwe the way it is at present, but it has the opportunity now to change for the better.

The Zimbabwean government is facing a difficult task in its attempts to improve country's situation. Factors it needs to take into account are, among others: the unfair distribution of land, lack of liquidity in banking system, reoccurring droughts, low level of healthcare, high costs of imports and exports that Zimbabwe has to face being a landlocked country. Moreover, the still echoing issue of land ownership has slowed down agricultural output. Other obstacles that are influencing overall economic recovery are: legal and trade system that discourages new investors, unstable energy and water supply, insufficient transport system, inflexible labor laws, high corruption. It's estimated that in the past, Zimbabwe had lost US\$15 billion income within diamond sector, because of lack of corporate governance and mismanagement. What is more, The African Development Bank assesses that Zimbabwe loses monthly almost US\$50 million due to gold smuggling (Bertelsmann Stiftung 2018).

Given that the coup was engineered by old ZANU-PF members and military generals, one can fear that nothing will in fact change. People who intervened had for years been profiting from Mugabe's system when it was working in their favor, but now it is hard to consider them as saviors of the country. M. Sithole said in 1986, "Unless we, as a people, can learn to respect our constitution and the legal rules of seeking and losing power, independence will not have been well worth fighting for and the thirty thousand will have died in vain!" (Sithole 1986, p. 95). Looking at his words, one starts to wonder how a modern Zimbabwe would look like, if Mugabe hadn't lost his way in attempts to hold on to power.

What can you expect from the elections scheduled for this year, 2018? One thing is certain, neither the leading party ZANU-PF, which has been in power for 37 years, nor MDC, its long-time opponent, will have an easy task. The programs they have been proposing are known inside and out to every Zimbabwean. On one hand, it can be expected that ZANU-PF will continue the patriotic discourse regarding the criticism of sanctions imposed by other countries on Zimbabwe, and remind citizens about the success of regaining independence and land reform. ZANU-PF will probably once again criticize the opposition, and in particular the MDC for being British puppets, and claim that their connections with Great Britain and America will always stand in the way of independent development of Zimbabwe. On the other hand, the opposition will point out all the mistakes and 
crises of the ruling party - violations of human rights, economic crisis, hyperinflation, deindustrialization and high unemployment.

Economic and social changes have taken place in Zimbabwe. As Nyamuda points out, for the first two decades, the political narrative was largely based on the "now infamous patriotic history narrative deployed to steer the power dynamics of the post colony." (Nyamunda 2017). Then the government moved to a more radical policy, especially when it came to redistributing land and commercial resources. No matter who will win in elections of 2018 'the challenge for the government will be to manage this tension between longer-term incremental change and popular demands for immediate economic relief, at a time when protest activism in Harare and other cities has tested state resilience in a new way" (Chityo, Vines, \& Vandome 2016, p. 5).

The opposition has been torn for years. Additionally, on February $14^{\text {th }} 2018$, MDC founder and leader, Morgan Tsvangirai, died after a long battle with cancer, leaving no set successor. Nelson Chamisa, 40 year old lawyer took the lead and maybe he can be the source of changes for Zimbabwe, a young candidate, who could appeal to younger generations and set the country on a new path. Another candidate can be Joice Mujuru, a former vice-president. She also claims that ZANU-PF campaigning, intimidation and bullying already started in rural areas, reminding people what happened in 2008 to the ones that voted for the opposition (The Economist 1.03.2018).

The current government hasn't done much to address the issues that have been there for a long time, among others: electoral reforms, freedom of speech, police brutality. For the upcoming elections, they promised to make them free and fair, but knowing this government, it won't be an easy task. However, it would give a new, fresh start to Zimbabwe, a country that has been held captive by its past for so long, one that deserves a new beginning and a brighter future. The country is wealthy in natural resources, favorable climate for agriculture and tourism, and young labor force. Infrastructure in Zimbabwe remains better than in many other African countries. Zimbabwe needs a government, which is people-oriented and focused on managing its resources properly. For years, everything has been on hold 'until Mugabe dies' and ZANU-PF lets go of power. For Zimbabwe to enter a new era, there should be a shift on political stage. Now, Zimbabwe has been given a chance to change things. It needs help itself set on a recovery path. A representative government, respect for human rights and fair elections is a good way to start.

\section{References}

Oliver R., Atmore A. (2007), Dzieje Afryki po 1800 roku, Warszawa.

Barnes J. (15.11.2017), “Zimbabwe coup: Military chief's full state media address after Robert Mugabe takeover", https:/www.express.co.uk/news/world/879796/Zimbabwe-coup-Robert-Mugabe-latest-news-full-speech-Major-General-SB-Moyo-ZBC (access: 13.03.2018). 
Bertelsmann Stiftung (2016), BTI 2016 - Zimbabwe Country Report, Gütersloh. Bertelsmann Stiftung (2018), BTI 2018 - Zimbabwe Country Report, Gütersloh.

Chityo K., Vines A., \& Vandome C. (2016), The Domestic and External Implications of Zimbabwe's Economic Reform and Re-engagement Agenda, The Royal Institute of International Affairs, Chatham.

Curtin P. (2003), “Europejski podbój”, in: P. Curtin et al., Historia Afryki, Gdańsk, pp. 553-568.

Curtin P. et al. (2003), Historia Afryki, Gdańsk.

Davidson B. (1972), Stara Afryka na nowo odkryta, Warszawa.

Ginifer J. (1995), Managing Arms in Peace Processes: Rhodesia/Zimbabwe, New York-Geneva. Gowland R. (2002), Zimbabwe: The Struggle for Land, The Struggle for Independence, Australia.

IRIN (13.11.2017), “Zimbabwe: What happens after Mugabe?", https://www.irinnews.org/opinion/2017/10/13/zimbabwe-what-happens-after-mugabe (access: 13.03.2018).

Lancaster House Agreement (1979), Southern Rhodesia Constitutional Conference held at Lancaster House, London, September-December 1979, http://sas-space.sas.ac.uk/5847/5/1979_Lancaster_House_Agreement.pdf (access: 16.02.2018).

Leśniewski M. (2000), “Zimbabwe czy Rodezja (1965-1981)”, in: Zarys dziejów Afryki i Azji, ed. A. Bartnicki, Warszawa, pp. 412-422.

Mandaza I. (1986), Zimbabwe: The Political Economy of Transition, 1980-1986, Dakar.

Mugabe R. (7.09.1993), "President Robert Mugabe's address to the ZANU-PF Central Committee meeting", http://www.postcolonialweb.org/zimbabwe/politics/mugabe.html (access: 16.02.2018).

Noko J. (2011), "Dollarization: The case of Zimbabwe", Cato Journal 31, no. 2, pp. 339-365.

Nyamunda T. (12.06.2017), "The limitations of Zimbabwe's contenting political economy paradigms", https://developingeconomics.org/2017/06/12/the-limitations-of-zimbabwes-contenting-political-economy-paradigms (access: 17.02.2018).

Peters B.L. (2003), "The political economy of land reform and agricultural development in Zimbabwe, Namibia and Mozambique", SA Yearbook of International Affairs, no. 4, pp. 343-349.

Pwiti G., Ndoro W. (1999), "The legacy of colonialism", African Archaeological Review 16, no. 3, pp. 143-153.

Seidman A. (1982), “A development strategy for Zimbabwe”, Zambezia, no. 10, pp. 13-39.

Simson H. (1979), Zimbabwe - a Country Study, The Scandinavian Institute for African Studies, Uppsala.

Thompson L. (2003), “Afryka Południowa do 1795 roku”, in: P. Curtin et al., Historia Afryki, Gdańsk, pp. 333-362.

The Choices Program (2009), Crisis in Zimbabwe, Watson Institute for International Studies, Brown University, Providence.

The Economist (21.02.2002), "Hell, no, I won’t go — Zimbabwe”, https://www.economist.com/ node/998658 (access: 5.03.2018).

The Economist (27.06.2002), "From breadbasket to basket case", https:/www.economist.com/ node/1201137 (access: 6.03.2018).

The Economist (5.03.2009), "Whose land?", https://www.economist.com/node/13240812 (access: 6.03.2018).

The Economist (12.05.2016), "Who wants to be a trillionaire?", https://www.economist.com/news/ middle-east-and-africa/21698658-lock-up-your-dollars-right-now-mugabenomics-back-who-wants-be (access: 18.03.2018).

The Economist (1.03.2018), “Zimbabwe's new president says he is a democrat. Is he?", https:// www.economist.com/news/middle-east-and-africa/21737529-emmerson-mnangagwa-says-some-sensible-things-has-yet-win-over (access: 18.03.2018).

The Guardian (15.03.2018), "Robert Mugabe says 'disgraceful' Zimbabwe coup must be undone", https://www.theguardian.com/world/2018/mar/16/robert-mugabe-zimbabwe-disgraceful-coup-must-be-undone (access: 18.03.2018).

Zins H. (2003), Historia Zimbabwe, Warszawa.

Ekonomia - Wroclaw Economic Review 24/1 (2018)

(C) for this edition by CNS 